Published in final edited form as:

Curr Org Chem. 2010 January ; 14(2): 138-147.

\title{
Advances in Bioconjugation
}

\author{
Jeet Kalia ${ }^{1,2}$ and Ronald T. Raines ${ }^{1,3,{ }^{*}}$ \\ ${ }^{1}$ Department of Biochemistry, University of Wisconsin-Madison, 433 Babcock Drive, Madison, \\ Wisconsin 53706-1544, USA \\ ${ }^{3}$ Department of Chemistry, University of Wisconsin-Madison, 1101 University Avenue, Madison, \\ Wisconsin 53706-1322, USA
}

\begin{abstract}
Bioconjugation is a burgeoning field of research. Novel methods for the mild and site-specific derivatization of proteins, DNA, RNA, and carbohydrates have been developed for applications such as ligand discovery, disease diagnosis, and high-throughput screening. These powerful methods owe their existence to the discovery of chemoselective reactions that enable bioconjugation under physiological conditions - a tremendous achievement of modern organic chemistry. Here, we review recent advances in bioconjugation chemistry. Additionally, we discuss the stability of bioconjugation linkages - an important but often overlooked aspect of the field. We anticipate that this information will help investigators choose optimal linkages for their applications. Moreover, we hope that the noted limitations of existing bioconjugation methods will provide inspiration to modern organic chemists.
\end{abstract}

\section{INTRODUCTION}

The enormous complexity and diversity of life presents an enormous challenge to scientists attempting to reveal its chemical basis. The discovery that genes contain the information required to generate proteins - the molecules that orchestrate biological processes-provided a universal axiom that enabled countless discovery-based investigations [1-3]. Deciphering the genetic composition of various organisms was a logical next step towards understanding biology. The ensuing whole-genome sequencing projects have yielded a wealth of information $[4,5]$.

The initial enthusiasm over the attainment of complete genetic information about various organisms has, however, been tempered by the realization that the utility of this information is nearly inactionable without knowledge of the function of the encoded proteins. Elucidation of the functions of other biomolecules, such as RNA and carbohydrates, is likewise imperative. "Bioconjugation", which refers to the covalent derivatization of biomolecules, provides a means to attain this goal [6-8]. This review focuses on modern methods for bioconjugation, and delineates both imperatives and means for making useful bioconjugates. We restrict our analysis to wild-type proteins composed of the 20 amino acids encoded by genetics, or close analogues thereof. Strategies involving the addition of an exogenous domain and its subsequent modification have been reviewed elsewhere [9-14].

\footnotetext{
*Address correspondence to this author at the Department of Biochemistry, University of, Wisconsin-Madison, 433 Babcock Drive, Madison, Wisconsin 53706-1544, USA; Tel: +1-608-262-8588; Fax: +1-608-890-2583; rtraines@ wisc.edu.

2 Current address: Molecular Physiology and Biophysics Section, Porter Neuroscience Research Center, National Institute of Neurological

Disorders and Stroke, 35 Convent Drive, Bethesda, MD 20892-3701, USA
} 


\section{MOTIVATION FOR BIOCONJUGATION}

\subsection{Discovery of Biological Interactions}

Proteins and other biopolymers regulate and perform biological functions by binding to ligands. Accordingly, discovering and characterizing the natural ligands of biopolymers is crucial to understanding biological processes. A promising approach for ligand discovery involves appending biomolecules of interest with synthetic small molecules that can function as probes that report on ligand binding [15]. Such probes include fluorescent molecules [16,17], biotin $[18,19]$, and NMR probes [20]. The ability to screen large numbers of potential ligands rapidly is highly desirable. An especially promising "high-throughput" approach involves the introduction of nonnatural functional groups into biomolecules, followed by site-specific immobilization on surfaces via a chemoselective reaction that occurs exclusively at the nascent appendage, as in Fig. (1). The immobilized biomolecule can be exposed subsequently to various molecules to identify ligands. DNA microarrays [21-23] and protein microarrays [24] are important examples of this approach.

\subsection{Biochemical Assays}

Small molecules appended to biomolecules can serve as probes for rigorous biochemical analyses. For example, Förster resonance energy transfer (FRET) can be used to generate signals that are sensitive to molecular conformational changes in the $1-10 \mathrm{~nm}$ range [25]. A typical FRET experiment entails attachment of a pair of fluorescent molecules to different regions of a biomolecule. One of these fluorophores serves as a "donor" by transferring energy nonradiatively to the other fluorophore, which serves as an "acceptor". Subsequently, the acceptor emits radiation at its characteristic emission frequency, thereby reporting on the distance between the donor and acceptor. FRET has been used to characterize protein folding [26], RNA folding [27,28], and biochemical reactions [29,30]. Modern single-molecule fluorescence approaches have elevated FRET-based approaches to an unprecedented level of specificity $[31,32]$.

Non-fluorescent small molecules are also employed as mechanistic probes. For example, biotin has been attached to a $\mathrm{K}^{+}$-ion channel, enabling the conformational changes accompanying channel opening to be mapped by measuring accessibility of the biotin to exogenous avidin [33]. In another example, a nitrile group was introduced into an enzyme as a vibrational probe, and its stretching frequency was a sensitive reporter of the electrostatic environment within the enzymic active site [34].

\subsection{Diagnostic Applications}

Qualitative and quantitative detection of analytes in clinical samples is crucial for the early diagnosis of disease. The complexity and heterogeneity of clinical samples presents a challenging environment for the detection of individual molecules. Chromatographic purification of analytes prior to analysis is time-consuming and labor-intensive, and hence impractical. Accordingly, chemical and immunological methods have become favored for medical diagnoses.

Clinical chemistry exploits an intrinsic physicochemical property of the analyte to generate a unique signal, thus circumventing analyte purification. Examples of this approach include spectrophotometric detection of metal ions and chromogenic and fluorogenic substrate-based assays for characterizing enzymes of interest [35]. Clinical chemistry approaches are limited to special cases because many analytes lack a unique signal-generating property. Moreover, clinical chemistry approaches are often not sensitive enough to be useful in clinical regimes. 
In comparison to chemical methods, immunological approaches are often more sensitive [36]. The high specificity of antibody-antigen interactions avoids sample purification. Moreover, since antibodies can be generated against almost any analyte, this method is widely applicable.

Traditional diagnostic methods require significant biochemical experimental protocols that are time-consuming and require specialized laboratory equipment, limiting their applicability. There is an urgent need to develop reusable biosensors for economical and rapid detection of analytes that would be usable in locations far removed from a laboratory setting, such as in the office of a medical doctor or in a remote geographical location. Most biosensors consist of biomolecules attached to surfaces via robust bioconjugation linkages. For example, a commercially available glucose sensor has been developed in which glucose oxidase is immobilized to an electrode surface. The immobilized enzyme converts glucose into hydrogen peroxide, which is recorded as a digital signal. This device is used to monitor glucose levels in diabetes patients [37]. Some biosensor applications employ optical techniques such as surface plasmon resonance (SPR) to detect binding of analytes to biomolecules immobilized on a surface. SPR is used to measure binding of ligands, and yields accurate binding constant values $[38,39]$. SPR-detection requires expensive instrumentation. A more practical and still highly sensitive detection method based on the orientational behavior of liquid crystals on nanostructured surfaces is demonstrating immense promise [40-43].

\subsection{Imaging in Vivo}

The diagnostic methods discussed above are limited to cases wherein the nature of the disease allows for the preparation of clinical samples. In many cases, sample preparation is unfeasible, and the diagnosis needs to be performed directly inside the body. Methods such as magnetic resonance imaging (MRI) and radioimaging are employed in such situations.

Contrast agents are used to improve signal-sensitivity in MRI. Gd(III) complexes are effective contrast agents [44-46]. Antibodies conjugated to Gd(III) complexes have been used for in vivo targeting [47]. Other contrast agents such as magnetite have also been conjugated to antibodies for similar applications [48].

Radioimaging is another powerful method for in vivo imaging. Isotopes of iodine (that is, ${ }^{123} \mathrm{I}$ and ${ }^{131} \mathrm{I}$ ) are commonly used radionuclides. The iodo group is especially convenient because it can be introduced readily into the tyrosine residues of proteins [49], but the observation of in vivo deiodination raises concerns [50]. Metal nuclides such as ${ }^{99 \mathrm{~m}} \mathrm{Tc}$ and ${ }^{111}$ In are useful alternatives, and can be attached to proteins via organic chelating agents such as EDTA [51].

Positron emission tomography (PET) continues to grow as an imaging tool. PET is used often in clinical oncology, as well as for the clinical diagnosis of certain diffuse brain diseases such as those causing various types of dementias. PET is also an important research tool to map normal human brain and heart function. PET relies on gamma rays emitted indirectly by a positron-emitting radionuclide, usually an $\left[{ }^{18} \mathrm{~F}\right]$ fluoro group attached to glucose. The conjugation of ${ }^{18} \mathrm{~F}$ to proteins is a promising area for future development [52].

\subsection{PEGylation}

The conjugation of polyethyleneglycol (PEG) molecules to proteins is a well-established technique. Commonly referred to as "PEGylation", attachment of PEGs can endow proteins with many desirable attributes, such as enhanced water solubility, reduced immunogenicity, improved circulating half-life in vivo, enhanced proteolytic resistance, reduced toxicity, and 
improved thermal and mechanical stability. PEGylation has been reviewed extensively [5355], and will not be discussed in detail here.

\subsection{Industrial Applications}

Immobilized enzymes are used as industrial catalysts [56,57]. The first commercial application of immobilized enzymes was the resolution of amino acids by an aminocyclase [58]. Applications in the food industry include use of fumarase to catalyze the isomerization of fumaric acid to malic acid. The pharmaceutical industry employs immobilized enzymes for the synthesis of drugs. For example, immobilized penicillin amidase is used in the preparation of 6-aminopenicillanic acid [59]. Applications of bioconjugation are also prevalent in the chemical industry. One prominent example is the use of immobilized nitrile hydratase for the production of acrylamide from acrylonitrile [60].

\section{BIOCONJUGATION LINKAGES}

Traditional strategies for covalent bioconjugation preclude control over the regiochemistry of reactions, producing heterogeneous reaction products, as in Fig. (1A). Poor control over the site of modification often results in loss of the biological function of the target biomolecule [61]. In contrast, novel methods of bioconjugation are highly site-specific and cause minimal perturbation to the active form of the biomolecule. Moreover, biomolecules immobilized sitespecifically can possess higher ligand binding ability [62-64,41], as in Fig. (1B), and display stronger spectral polarization [65]. Thus, site-specific bioconjugation is preferable to random bioconjugation. Common linkages for site-specific bioconjugation rely on cysteine or lysine residues. Newer methods target nonnatural functional groups [66], including olefins via metathesis $[67,68]$. Chemical reactions that target tryptophan and tyrosine have been reviewed elsewhere [69].

\subsection{Linkages Containing Thioethers}

Thiolates (though not thiols [70]) are potent nucleophiles in aqueous solutions. Accordingly, the derivatization of proteins via the thiolate group of a cysteine residue is a popular method of bioconjugation [71]. As cysteine is the second least common amino acid in natural proteins [72], site-specific conjugation can often be performed at a unique cysteine residue.

Typical thiol-reactive functional groups include iodoacetamides, maleimides, and disulfides, as in Fig. (2). Iodoacetamides (Fig. (2A)) were used in classic experiments for determining the presence of free cysteines in proteins [73]. More recently, iodoacetamido groups have been used extensively for labeling proteins with fluorophores, PEGylation, and protein immobilization [6]. Chloroacetamides appear to exhibit even greater specificity than iodoacetamides for cysteine residues [74].

Like iodoacetamides, maleimides are commonly used electrophiles for thiol-mediated bioconjugation $[6,7,75,8,74]$. Thiolates undergo a Michael addition reaction with maleimides to form succinimidyl thioethers (Fig. (2B)). An undesirable and underappreciated aspect of maleimide conjugates is the susceptibility of their imido groups to undergo spontaneous hydrolysis, resulting in undesirable heterogeneity. Both molybdate and chromate have been shown to catalyze the hydrolysis of an imido group near neutral $\mathrm{pH}$ [76], providing a means to decrease the heterogeneity of bioconjugates derived from maleimides.

The thiol-selectivity of iodoacetamides and maleimides is compromised at high concentrations of the reagents, as nucleophilic side chains of amino acid residues such as histidines and lysines can be modified covalently. In contrast, disulfide reagents react selectively with thiols, as in Fig. (2C). Disulfides are, however, susceptible to reduction by biological reducing agents, like glutathione. Hence, the use of disulfides is limited to in vitro applications, such as the 
crosslinking [77,78] and immobilization [79] of peptides and proteins. Thiol-disulfide interchange is also the basis of an innovative tethering method that enables the identification of small-molecule fragments that bind to specific regions of a target protein [80].

\subsection{Linkages Containing Amide Bonds}

Amide bonds have a half life of $c a$. 600 years in neutral solution at $25^{\circ} \mathrm{C}$ [81]. This extraordinary stability makes amide linkages highly attractive for bioconjugation. The random introduction of amide linkages in biomolecules is trivial. For example, a protein can be treated with a small molecule or surface displaying an activated ester (e.g., an $N$-hydroxysuccinimidyl ester) to form amide bonds with the amino groups on lysine side chains and the $\mathrm{N}$ terminus $[82,41]$. In contrast, the site-specific generation of amides is challenging. Native chemical ligation and the Staudinger ligation are two modern approaches for generating amide linkages at a specific site in a protein [83].

In native chemical ligation, an $\mathrm{N}$-terminal cysteine residue reacts with a thioester to undergo transthioesterification followed by a rapid $S \rightarrow N$ acyl transfer to form an amide, as in Fig. (3). This reaction is a powerful tool for peptide ligation and hence protein synthesis [84-88]. Expressed protein ligation is an extension of native chemical ligation [89-91]. In this method, a target protein is expressed as a fusion protein with an intein - a protein subunit that catalyzes the formation of a thioester at the C-terminus of the target protein, as in Fig. (4). The proteinintein fusion proteins are treated with peptides containing an $\mathrm{N}$-terminal cysteine residue to effect native chemical ligation, as in Fig. (3). Surfaces displaying cysteines were treated with protein-intein thioesters to perform site-specific protein immobilization via amide bonds [92]. Using a similar approach, fluorescent molecules were conjugated to specific sites in proteins [93]. Furthermore, proteins were biotinylated using expressed protein ligation, and then used for high-throughput proteomic analyses [94]. An undesirable aspect of native chemical ligation and expressed protein ligation is the introduction of a residual thiol at the site of bioconjugation, which can be a focal point for undesirable side reactions [95-97]. Chemical desulfurization approaches [98] provide a solution to the above problem, but are obviated if the protein contains other cysteine residues. Hydrazine nucleophiles react with protein-intein thioesters without installing a residual reactive group, and enable a functional group [99] or surface [100] to be appended at the C terminus of a protein, as in Fig. (4).

The Staudinger ligation provides another solution to the cysteine limitation $[101,83]$. This conjugation method is based on the venerable Staudinger reaction, in which an azide is reduced to an amine by a phosphine $[102,103]$. Staudinger ligation employs a phosphine that also serves as an acyl donor-the phosphorus first attacks the azide forming an iminophosphorane, which is then acylated with the concomitant liberation of nitrogen gas to form an amidophosphonium salt that hydrolyzes to yield the amide [104,105]. One version of the Staudinger ligation leaves a phosphine oxide in the amide product, as in Fig. (5A) [106,107,104]. Another version-the "traceless" Staudinger ligation-employs a phosphinothioester that yields an acyclic amidophosphonium salt, resulting in an amide product that lacks the phosphine oxide moiety or other residual atoms, as in Fig. (5B) [108-111,83,105,112].

The Staudinger ligation is used often for bioconjugation. The initial uses were with azidocontaining carbohydrates introduced onto cell surfaces by biosynthesis, and enabled quantitative measurements by flow cytometry $[106,113]$. Subsequently, the Staudinger ligation has been used for $N$-glycopeptide synthesis [114]. In addition, an azido group has been installed into a protein by using the methionyl-tRNA synthetase of Escherichia coli activated with $\gamma$ azidohomoalanine, and then subjected to Staudinger ligation with a peptide [115]. Azido groups have also been installed into proteins by diazo transfer [116]. The Staudinger ligation has been used for the rapid and site-specific immobilization of peptides and proteins [117,64, $118,100]$. Water-soluble reagents for the traceless version avail new possibilities, such as 
integration with expressed protein ligation. The site-specific labeling of DNA by fluorescent molecules has also been performed by Staudinger ligation [119]. A phosphinothiol that mediates the traceless Staudinger ligation also reacts with $S$-nitrosothiols to generate bisconjugates [120]. Finally, a gentle phosphine-mediated means to convert an azido group into a diazo compound - a ready precursor to a carbene—provides the potential for random crosslinking to biomolecules, as in Fig. (5C) [121].

The special reactivity of squarates has been exploited for bioconjugation (Fig. (6)) [122124]. The reaction of two amino groups with a squarate results in their conjugation via two vinylogous amides. Notable advantages of this conjugation method include the small size of the squarate, and the greatly reduced rate of its reaction with the second amino group, limiting the undesirable synthesis of homodimers.

\subsection{Linkages Containing Carbon-Nitrogen Double Bonds}

The facile synthesis of carbon-nitrogen double bonds via condensation of nitrogen bases with aldehydes and ketones in aqueous solutions at neutral $\mathrm{pH}$ renders them attractive for bioconjugation. Hydrazones $(\mathrm{C}=\mathrm{N}-\mathrm{N})$ are generated when the nitrogen base is a hydrazine, as in Fig. (7). Oximes $(\mathrm{C}=\mathrm{N}-\mathrm{O})$ are formed when the nitrogen base is an alkoxyamine. Both hydrazones and oximes are significantly more stable than are simple imines $(\mathrm{C}=\mathrm{N})$ - the products of condensation of amines with aldehydes or ketones. Anilines are, however, especially effective catalysts of hydrazone and oxime formation [125-128].

Carbohydrates are especially amenable to modification with carbon-nitrogen double bonds, as their hydroxyl groups can be oxidized readily into aldehydes [129]. Alternatively, ketones can be introduced into cell-surface carbohydrates by biosynthesis [130,131]. Carbohydrates immobilized via oxime linkages have been used to generate carbohydrate microarrays [132].

There are numerous examples in the literature of hydrazone and oxime conjugates of oligonucleotides [133]. For example, acylhydrazone linkages have been used for the immobilization of aldehydic oligonucleotides on surfaces displaying acylhydrazines [134]. Additionally, peptide nucleic acid-peptide conjugates have been generated using oxime conjugation [135].

Peptide microarrays generated by immobilizing peptides via acylhydrazone linkages enable the sensitive detection of antibodies in blood samples [136,137]. Peptides and small molecules have been immobilized via oxime linkages onto glass slides displaying aldehydes, and the resulting microarrays used for protein binding and cell-adhesion assays [138]. Peptide fragments bearing aminoxy functional groups were incubated with a polyaldehyde template to generate large protein-like molecules containing multiple oxime linkages $[139,140]$. The chemoselectivity of oxime formation has been used to assemble a transcription factor-related protein that is not readily accessible by recombinant DNA technology [141]. A conceptually related approach was used to synthesize glycodendrimers appended with an antigen [142, 143]. Finally, oxidative deamination mediated by pyridoxal 5'-phosphate can be used to generate an aldehyde or ketone at the $\mathrm{N}$ terminus of some peptides and proteins [144,145].

Although hydrazones and oximes are common conjugates, both are labile to spontaneous hydrolysis. The hydrolytic stabilities of isostructural alkylhydrazones, acylhydrazones, and an oxime were examined at pD 5.0-9.0 [146]. The hydrolysis of each adduct was found to be catalyzed by acid. Rate constants for oxime hydrolysis were nearly $10^{3}$-fold lower than those for the hydrazones; a trialkylhydrazonium ion (formed after condensation) was even more stable than the oxime. These data led to a general mechanism for the hydrolysis of $\mathrm{C}=\mathrm{N}-\mathrm{X}$ linkages. There are several important messages from this work. First, alkylhydrazones and acylhydrazones should not be used for bioconjugation, as their half-lives are only an hour or 
so under physiological conditions. Secondly, oximes are far more stable than hydrazones, having half-lives close to a month. Finally, efforts to develop a gentle means to condense a trialkylhydrazine with an aldehyde or ketone are worthwhile.

\subsection{Linkages Generated by Cycloaddition}

The discovery of the rate acceleration availed by $\mathrm{Cu}(\mathrm{I})$ has made the Huisgen 1,3-dipolar azidealkyne cycloaddition one of the most useful reactions for bioconjugation [147-151]. This cycloaddition results in the irreversible formation of a 1,4-disubstituted[1,2,3]triazole linkage, as in Fig. (5D). The reaction has been used in an extraordinary range of contexts, including labeling proteins with small molecules $[152,99,153,154]$, immobilizing proteins and peptides [155,118], proteomics applications [156], immobilizing carbohydrates [155], functionalizing DNA [155,157], and decorating virus particles and bioactive polymers with fluorescent molecules [158,159]. A Ru(II) catalyst leads to the 1,5-disubstituted[1,2,3]triazole [160], which mimics a cis (that is, E) peptide bond [161], as in Fig. (5E).

The $\mathrm{Cu}(\mathrm{I})$-catalyzed version of the Huisgen cycloaddition can cause cytotoxicity and protein precipitation due to the $\mathrm{Cu}(\mathrm{I})$ ion $[156,99]$. Moreover, the reaction rates are slow, precluding its use for studying cellular processes. To overcome these drawbacks, several groups have exploited a reaction discovered in the 1950s [162,163] and exploited latterly [164], using the ring strain of a cyclooctyne group to enable the Huisgen 1,3-dipolar azide-alkyne cycloaddition to proceed rapidly without a catalyst [165-167], as in Fig. (5F).

Another cycloaddition reaction - the Diels-Alder reaction—between a diene on a peptide and a dienophile on a glass surface has been used for peptide immobilization [168]. A similar approach was employed for immobilizing carbohydrates onto glass slides displaying hydroquinone functional groups [169]. The inverse-electron-demand Diels-Alder reaction between a tetrazine and trans-cyclooctene is especially rapid and has much potential for bioconjugation [170].

\subsection{Chemoselectivity and Kinetics}

Of the functional groups described above, the azido group is foremost in having an intrinsic reactivity that is versatile though relatively chemoselective under physiological conditions (Fig. (5)) [171,172]. Accordingly, the Staudinger ligation and Huisgen 1,3-dipolar azidealkyne cycloaddition have gained special favor amongst chemical biologists. There are, however, two limitations to consider.

The first limitation is the relatively low chemoselectivity of azide coreactants. The oxidizing extracellular environment is electron-poor, and hence replete with electrophiles. Prevalent there are disulfide bonds and singlet oxygen, which can react rapidly with the phosphines of the Staudinger ligation. Conversely, the reducing environment of the cytosol is electron-rich and awash with nucleophilic thiolates that can attack cyclooctyne and its congeners (including trans-cyclooctene). Although these bioconjugation reactions are compromised by coreactant promiscuity, extracellular Huisgen cycloadditions avoid the most calamitous of side reactions.

The second limitation is the rather modest reaction rate constants of azide-mediated conjugation reactions. The second-order rate constant for the fastest known Staudinger ligation is $7.7 \times 10^{-3} \mathrm{M}^{-1} \mathrm{~s}^{-1}$ [105]. That for the most rapid Huisgen cycloaddition is $2.3 \mathrm{M}^{-1} \mathrm{~s}^{-1}$ [167]. What do these rate constants mean for a chemical biologist? Consider a bioconjugation reaction between equimolar reactants $\mathrm{A}$ and $\mathrm{B}$ to form $\mathrm{A}-\mathrm{B}$ with second-order rate constant $k$ : 


$$
\mathrm{A}+\mathrm{B} \stackrel{k}{\rightarrow} \mathrm{A}-\mathrm{B}
$$

Integrating the rate equation gives

$$
\frac{1}{[\mathrm{~A}]_{t}}-\frac{1}{[\mathrm{~A}]_{t=0}}=k t
$$

and the yield $=[\mathrm{A}-\mathrm{B}]_{t} /[\mathrm{A}]_{t=0}$ of conjugate is

$$
\text { yield }=\frac{k t[\mathrm{~A}]_{t=0}}{1+k t[\mathrm{~A}]_{t=0}}
$$

If attainable concentrations of $[\mathrm{A}]_{t=0}=[\mathrm{B}]_{t=0}=1 \mu \mathrm{M}$ are allowed to react for a reasonable time of $t=1 \mathrm{~h}$ without any side reactions, then the fastest known Staudinger ligation and Huisgen cycloaddition would provide A-B yields of $0.003 \%$ and $0.8 \%$, respectively. For comparison, we note that highly chemoselective enzyme-mediated conjugation reactions can occur with a second-order rate constant of $2.7 \times 10^{6} \mathrm{M}^{-1} \mathrm{~s}^{-1}$ [173], which would provide an A-B yield of $>90 \%$. This value provides a benchmark for the development of rapid but still chemoselective reactions for biological contexts.

\section{CONCLUSIONS}

Bioconjugation is being applied in research laboratories, industrial facilities, and medical clinics. Choosing the optimal linkage for a particular application is crucial. One imperative is the ease of generating the desired bioconjugate quickly under physiological conditions.

Another is the stability of the bioconjugate during the course of its use. These imperatives present interesting challenges of substantial importance. As a consequence, new conjugation modalities are being pursued with vigor.

\section{Acknowledgments}

Work on bioconjugation in our laboratory is supported by grant NIH GM044783 and the Materials Research Science and Engineering Center at the University of Wisconsin-Madison (NSF DMR-0520527).

\section{REFERENCES}

1. Crick FH. On protein synthesis. Symp. Soc. Exp. Biol 1958;12:139-163.

2. Crick FH. Central dogma of molecular biology. Nature 1970;227:561-563. [PubMed: 4913914]

3. McCarty, M. The Transforming Principle: Discovering that Genes are Made of DNA. New York: W. W. Norton; 1985.

4. Lander ES, Linton LM, Birren B, Nusbaum C, Zody MC, Baldwin J, Devon K, Dewar K, Doyle M, FitzHugh W, Funke R, Gage D, Harris K, Heaford A, Howland J, Kann L, Lehoczky J, LeVine R, McEwan P, McKernan K, Meldrim J, Mesirov JP, Miranda C, Morris W, Naylor J, Raymond C, Rosetti M, Santos R, Sheridan A, Sougnez C, Stange-Thomann N, Stojanovic N, Subramanian A, Wyman D, Sulston J, Ainscough R, Beck S, Bentley D, Burton J, Clee C, Carter N, Coulson A, Deadman R, Deloukas P, Dunham A, Dunham I, Durbin R, French L, Grafham D, Gregory S, Hubbard T, Humphray S, Hunt A, Jones M, Lloyd C, McMurray A, Matthews L, Mercer S, Milne S, Mullikin JC, Mungall A, Plumb R, Ross M, Shownkeen R, Sims S, Waterston RH, Wilson RK, Hillier LW, McPherson JD, Marra MA, Mardis ER, Fulton LA, Chinwalla AT, Pepin KH, Gish WR, Chissoe SL, Wendl MC, Delehaunty KD, Miner TL, Delehaunty A, Kramer JB, Cook LL, Fulton RS, Johnson DL, Minx PJ, Clifton SW, Harkins T, Branscomb E, Predki P, Richardson P, Wenning S, Slezak T, Doggett N, Cheng 
J-F, Olsen A, Lucas S, Elkin C, Uberbacher E, Frazier M, Gibbs RA, Muzny DM, Scherer SE, Bouck JB, Sodergren EJ, Worley KC, Rives CM, Gorrell JH, Metzker ML, Naylor SL, Kurcherlapati RS, Nelson DL, Weinstock GM, Sakaki Y, Fujiyama A, Hattori M, Yada T, Toyoda A, Itoh T, Kawagoe C, Watanabe H, Totoki Y, Taylor T, Weissenbach J, Heilig R, Saurin W, Artiguenave F, Brottier P, Bruls T, Pelletier E, Robert C, Wincker P, Smith DR, Doucette-Stamm L, Rubenfield M, Weinstock K, Lee HM, Dubois J, Rosenthal A, Platzer M, Nyakatura G, Taudien S, Rump A, Yang H, Yu J, Wang J, Huang G, Gu J, Hood L, Rowen L, Madan A, Qin S, Davis RW, Federspiel NA, Pia Abola A, Proctor MJ, Schmutz J, Dickson M, Grimwood J, Cox DR, Olson MV, Kaul R, Raymond C, Shimizu N, Kawasaki K, Minoshima S, Evans GA, Athanasiou M, Schutlz R, Roe BA, Chen F, Pan H, Ramser J, Lehrach H, Reinhardt R, McCombie WR, de la Bastide M, Dedhia N, Blocker H, Hornischer K, Nordsiek G, Agarwala R, Aravind L, Bailey JA, Bateman A, Batzoglou S, Birney E, Bork P, Brown DG, Burge CB, Cerutti L, Chen H-C, Church D, Clamp M, Copley RR, Doerks T, Eddy SR, Eichler EE, Furey TS, Galagan J, Gilbert JGR, Harmon C, Hayashizaki Y, Haussler D, Hermjakob H, Hokamp K, Jang W, Johnson LS, Jones TA, Kasit S, Kaspryzk A, Kennedy S, Kent WJ, Kitts P, Koonin EV, Kort I, Kulp D, Lancet D, Lowe TM, McLysaght A, Mikkelsen T, Moran JV, Mulder N, Pollara VJ, Ponting CP, Schuler G, Schultz J, Slater G, Smit A, Stupka E, Szustakowki J, Thierry-Mieg D, ThierryMieg J, Wagner L, Wallis J, Wheeler R, Williams A, Wolf YI, Wolfe KH, Yang S-Pg, Yeh R-F, Collins F, Guyer MS, Peterson J, Felsenfeld A, Wetterstrand KA, Patrinos A, Morgan MJ. Initial sequencing and analysis of the human genome. Nature 2001;409:860-921. [PubMed: 11237011]

5. Venter JC, Adams MD, Myers EW, Li PW, Mural RJ, Sutton GG, Smith HO, Yandell M, Evans CA, Holt RA, Gocayne JD, Amanatides P, Ballew RM, Huson DH, Wortman JR, Zhang Q, Kodira CD, Zheng XH, Chen L, Skupski M, Subramanian G, Thomas PD, Zhang J, Miklos GLG, Nelson C, Broder S, Clark AG, Nadeau J, McKusick VA, Zinder N, Levine AJ, Roberts RJ, Simon M, Slayman C, Hunkapiller M, Bolanos R, Delcher A, Dew I, Fasulo D, Flanigan M, Florea L, Halpern A, Hannenhalli S, Kravitz S, Levy S, Mobarry C, Reiner K, Remington K, Abu-Threide J, Beasle E, Biddick K, Bonazzi V, Brandon R, Cargill M, Chandramouliswaran I, Charlab R, Chaturved K, Deng Z, Di Francesco V, Dunn P, Eilbeck K, Evangelista C, Gabrielian AE, Gan W, Ge W, Gon F, Gu Z, Guan P, Heiman TJ, Higgins ME, Ji R-R, Ke Z, Ketchum KA, Lai Z, Lei Y, Li Z, Li J, Liang Y, Lin X, Lu F, Merkulov GV, Milshina N, Moore HM, Naik AK, Narayan VA, Neelam B, Nusskern D, Rusch DB, Salzberg S, Shao W, Shue B, Sun J, Wang ZY, Wang A, Wang X, Wang J, Wei M-H, Wides R, Xiao C, Yan C, Yao A, Ye J, Zhan M, Zhan W, Zhang H, Zhao Q, Zheng L, Zhong F, Zhong W, Zhu SC, Zhao S, Gilbert D, Baumhueter S, Spier G, Carter C, Cravchik A, Woodage T, Ali F, An H, Awe A, Baldwin D, Baden H, Barnstead M, Barrow L, Beeson K, Busam D, Carver A, Center A, Cheng ML, Curry L, Danaher S, Davenport L, Desilets R, Dietz S, Dodson K, Doup L, Ferriera S, Garg N, Hostin D, Houck J, Howland T, Ibegwam C, Johnson J, Kalush F, Kline L, Koduru S, Love A, Mann F, May D, Nelson K, Pfannkoch C, Pratts E, Puri V, Qureshi H, Reardon M, Rodriguez R, Rogers Y-H, Romblad D, Ruhfel B, Scott R, Sitter C, Smallwood M, Stewart E, Strong R, Suh E, Thomas R, Tint NN, Tse S, Vech C, Wang G, Wetter J, Williams S, Williams M, Windsor S, Winn-Deen E, Wolfe K, Zaveri J, Zaveri K, Abril JF, Guigo R, Campbell MJ, sjolander KV, Karlak B, Kejariwal A, Mi H, Lazareva B, Hatton T, Narechania A, Diemer K, Muruganujan A, Guo N, Sato S, Bafna V, Istrail S, Lippert R, Schwartz R, Walenz B, Yooseph S, Allen D, Basu A, Baxendale J, Block L, Caminha M, Carnes-Stine J, Caulk P, Chiang Y-h, Coyne M, Dahike C, Mays AD, Dombroski M, Donnelly M, Ely D, Esparham S, Foster C, Gire H, Glanowski S, Glasser K, Glodek A, Gorokhov M, Graham K, Gropman B, Harris M, Heil J, Henderson S, Hoover J, Jennings D, Jordan C, Jordan J, Kasha J, Kagan L, Kraft C, Levitsky A, Lewis M, Liu X, Lopez J, Ma D, Majoros W, McDaniel J, Murphy S, Newman M, Nguyen T, Nguyen N, Nodell M, Pan S, Peck J, Peterson M, Rowe W, Sanders R, Scott J, Simpson M, Smith T, Sprague A, Stockwell T, Turner R, Venter E, Wang M, Wen M, Wu D, Xia A, Zandieh A, Zhu X. The sequence of the human genome. Science 2001;291:1304-1351. [PubMed: 11181995]

6. Aslam, M.; Dent, A. Bioconjugation: Protein Coupling Techniques for the Biomedical Sciences. London: Macmillan Reference Ltd; 1998.

7. Lundblad, RL. Chemical Reagents for Protein Modification. 3rd ed.. Boca Raton, FL: CRC Press; 2005.

8. Hermanson, GT. Bioconjugate Techniques. 2nd ed.. San Diego, CA: Academic Press; 2008.

9. Miller LW, Cornish VW. Selective chemical labeling of proteins in living cells. Curr. Opin. Chem. Biol 2005;9:56-61. [PubMed: 15701454]

10. Marks KM, Nolan GP. Chemical labeling strategies for cell biology. Nat. Meth 2006;3:591-596. 
11. Eisenstein M. Helping cells to tell a colorful tale. Nat. Meth 2006;3:647-655.

12. Johnsson H, Johnsson K. Chemical tools for biomolecular imaging. ACS Chem. Biol 2007;23:3138. [PubMed: 17243781]

13. O'Hare HM, Johnsson K, Gautier A. Chemical probes shed light on protein function. Curr. Opin. Struct. Biol 2007;17:488-494. [PubMed: 17851069]

14. Fernández-Suárez M, Ting AY. Fluorescent probes for super-resolution imaging in living cells. Nat. Rev. Mol. Cell Biol 2008;9:929-943. [PubMed: 19002208]

15. Rup B, O'Hara D. Critical ligand binding reagent preparation/selection: When specificity depends on reagents. AAPS J 2007;9:E148-E155. [PubMed: 17614357]

16. Lavis LD, Raines RT. Bright ideas for chemical A. ACS Chem. Biol 2008;3:142-155. [PubMed: 18355003]

17. Gonçalves MST. Fluorescent labeling of biomolecules with organic probes. Chem. Rev 2009;109:190-212. [PubMed: 19105748]

18. Jannatipour M, Dion P, Khan S, Jindal H, Fan X, Laganiere J, Chishti AH, Rouleau GA. Schwannomin isoform-1 interacts with syntenin via PDZ domains. J. Biol. Chem 2001;276:33093-33100. [PubMed: 11432873]

19. Ducoux M, Urbach S, Baldacci G, Hubscher U, Koundrioukoff S, Christensen J, Hughes P. Mediation of proliferating cell nuclear antigen (PCNA)-dependent DNA replication through a conserved p21 Cip1-like PCNA-binding motif present in the third subunit of human DNA polymerase $\delta$. J. Biol. Chem 2001;276:49258-49266. [PubMed: 11595739]

20. Pellecchia M, Sem DS, Wuthrich K. NMR in drug discovery. Nat. Rev. Drug Discov 2002;1:211219. [PubMed: 12120505]

21. Lipshutz RJ, Fodor SPA, Gingeras TR, Lockhard DJ. High density synthetic oligonucleotide arrays. Nat. Genet 1999;21:20-24. [PubMed: 9915496]

22. Brown PO, Botstein D. Exploring the new world of the genome with DNA microarrays. Nat. Genet 1999;21:33-37. [PubMed: 9915498]

23. Hoheisel JD. Microarray technology: Beyond transcript profiling and genotype analysis. Nat. Rev. Genet 2006:200-210. [PubMed: 16485019]

24. Jonkheijm P, Weinrich D, Schröder H, Niemeyer CM, Waldmann H. Chemical strategies for generating protein biochips. Angew. Chem. Int. Ed 2008;47:9618-9647.

25. Jares-Erijman EA, Jovin TM. FRET imaging. Nat. Biotechnol 2003;21:1387-1395. [PubMed: 14595367]

26. Schuler B, Eaton WA. Protein folding studied by single-molecule FRET. Curr. Opin. Struct. Biol 2008;18:16-26. [PubMed: 18221865]

27. Bokinsky G, Zhuang X. Single-molecule RNA folding. Acc. Chem. Res 2005;38:566-573. [PubMed: 16028891]

28. Smith GJ, Lee KT, Qu X, Xie Z, Pesic J, Sosnick TR, Pan T, Scherer NF. A large collapsed-state RNA can exhibit simple exponential single-molecule dynamics. J. Mol. Biol 2008;378:941-951.

29. Kersteen EA, Barrows SR, Raines RT. Catalysis of protein disulfide bond isomerization in a homogeneous substrate. Biochemistry 2005;44:12168-12178. [PubMed: 16142915]

30. Newman RH, Zhang J. Visualization of phosphatase activity in living cells with a FRET-based calcineurin activity sensor. Mol. Biosyst 2008;4:496-501. [PubMed: 18493642]

31. Ha T, Enderle T, F OD, Chemla DS, Selvin PR, Weiss S. Probing the interaction between two single molecules: Fluorescence resonance energy transfer between a single donor and a single acceptor. Proc. Natl. Acad. Sci. U.S.A 1996;93:6264-6268. [PubMed: 8692803]

32. Cornish PV, Ha T. A survey of single-molecule techniques in chemical biology. ACS Chem. Biol 2007;2:53-61. [PubMed: 17243783]

33. Jiang Y, Ruta V, Chen J, Lee A, MacKinnon R. The principle of gating charge movement in a voltagedependent $\mathrm{K}^{+}$channel. Nature 2003;423:42-48. [PubMed: 12721619]

34. Sigala PA, Fafarman AT, Bogard PE, Boxer SG, Herschlag D. Do ligand binding and solvent exclusion alter the electrostatic character within the oxyanion hole of an enzymatic active site? J. Am. Chem. Soc 2007;129:12104-12105. [PubMed: 17854190] 
35. Burtis, CA.; Ashwood, ER. Tietz Textbook of Clinical Chemistry. 2nd ed.. Philadelphia, PA: W. B. Saunders; 1994.

36. Price, CP.; Newman, DJ. Principles and Practice of Immunoassay. 2nd ed.. London: Macmillan Reference Ltd; 1997.

37. Heller A, Feldman B. Electrochemical glucose sensors and their applications in diabetes management. Chem. Rev 2008;108:2482-2505. [PubMed: 18465900]

38. Hartmann-Petersen R, Gordon C. Quantifying protein-protein interactions in the ubiquitin pathway by surface plasmon resonance. Methods Enzymol 2005;399:164-177. [PubMed: 16338355]

39. Aslan K, Lakowicz JR, Geddes CD. Plasmon light scattering in biology and medicine: New sensing approaches, visions and perspectives. Curr. Opin. Chem. Biol 2005;9:538-544. [PubMed: 16129649]

40. Gupta VK, Skaife JJ, Dubrovsky TB, Abbott NL. Optical amplification of ligand-receptor binding using liquid crystals. Science 1998;279:2077-2080. [PubMed: 9516101]

41. Luk Y-Y, Tingey ML, Dickson KA, Raines RT, Abbott NL. Comparison of the binding activity of randomly oriented and uniformly oriented proteins immobilized by chemoselective coupling to a self-assembled monolayer. J. Am. Chem. Soc 2004;126:9024-9032. [PubMed: 15264835]

42. Bertics PJ, Ozer BH, Wiepz GJ, Guadarrama AG, Abbott NL, Lowe AM, Shusta EV, Agarwal N, Raines RT, Kalia J. Liquid crystal-based analytic technology: Enabling a molecular view of cancer. BIOforum Europe 2007;11:42-45.

43. Lowe AM, Bertics PJ, Abbott NL. Quantitative methods based on twisted nematic liquid crystals for mapping surfaces patterned with bio/chemical functionality relevant to bioanalytical assays. Anal. Chem 2008;80:2637-2645. [PubMed: 18355089]

44. Caravan P. Strategies for increasing the sensitivity of gadolinium based MRI contrast agents. Chem. Soc. Rev 2006;35:512-523. [PubMed: 16729145]

45. Allen MJ, Raines RT, Kiessling LL. Contrast agents for magnetic resonance imaging synthesized with ring-opening metathesis polymerization. J. Am. Chem. Soc 2006;128:6534-6535. [PubMed: 16704234]

46. Werner EJ, Datta A, Jocher CJ, Raymond KN. High-relaxivity MRI contrast agents: Where coordination chemistry meets medical imaging. Angew. Chem. Int. Ed 2008;47:8568-8580.

47. Shreve P, Aisen AM. Monoclonal antibodies labeled with polymeric paramagnetic ion chelates. Magn. Reson. Med 1986;3:336-340. [PubMed: 3713499]

48. Tiefenauer LX, Kuhne G, Andres RY. Antibody-magnetite nanoparticles: In vitro characterization of a potential tumor-specific contrast agent for magnetic resonance imaging. Bioconjugate Chem 1993;4:347-352.

49. Holohan KN, Murphy RF, Flanagan RW, Buchanan KD, Elmore DT. Enzymic iodination of the histidyl residue of secretin: A radioimmunoassay of the hormone. Biochim. Biophys. Acta 1973;322:178-180. [PubMed: 4744332]

50. Bianco AC, Kim BW. Deiodinases: Implications of the local control of thyroid hormone action. J. Clin. Invest 2006;116:2571-2579. [PubMed: 17016550]

51. Parker D. Tumor targeting with radio-labeled macrocycle-antibody conjugates. Chem. Soc. Rev 1990;19:271-291.

52. Wester HJ, Schottelius M. Fluorine-18 labeling of peptides and proteins. Ernst Schering Res. Found. Workshop 2007:79-111. [PubMed: 17172153]

53. Zalipsky S. Functionalized poly(ethylene glycol) for preparation of biologically relevant conjugates. Bioconjugate Chem 1995;6:150-165.

54. Roberts MJ, Bentley MD, Harris JM. Chemistry for peptide and protein PEGylation. Adv. Drug. Deliv. Rev 2002;54:459-479. [PubMed: 12052709]

55. Chapman AP. PEGylated antibodies and antibody fragments for improved therapy: A review. Adv. Drug. Deliv. Rev 2002;54:531-545. [PubMed: 12052713]

56. Chibata, I. Immobilized Enzymes: Research and Development. New York: John Wiley \& Sons; 1979.

57. Wong, C-H.; Whitesides, GM. Enzymes in Synthetic Organic Chemistry. Tarrytown, NY: Elsevier Science; 1994. 
58. Tosa T, Mori T, Fuse N, Chibata I. Studies on continuous enzyme reactions. IV. Preparation of a DEAE-Sephadex-aminoacyclase column and continuous optical resolution of acyl-dl-amino acids. Biotechnol. Bioeng 1967;9:603-615.

59. Lagerlof E, Nathorst-Westfelt L, Ekstrom B, Sjoberg B. Production of 6-aminopenicillanic acid with immobilized Escherichia coli acylase. Methods Enzymol 1976;44:759-768. [PubMed: 191731]

60. Kobayashi M, Nagasawa T, Yamada H. Enzymatic synthesis of acrylamide: A success story not yet over. Trends Biotechnol 1992;10:402-408. [PubMed: 1368882]

61. Cha T, Guo A, Zhu XY. Enzymatic activity on a chip: The critical role of protein orientation. Proteomics 2005;5:416-419. [PubMed: 15627963]

62. Peluso P, Wilson DS, Do D, Tran H, Venkatasubbaiah M, Quincy D, Heidecker B, Poindexter K, Tolani H, Phelan M, Witte K, Jung LS, Wagner P, Nock S. Optimizing antibody immobilization strategies for the construction of protein microarrays. Anal. Biochem 2003;312:113-124. [PubMed: 12531195]

63. Du Y-Z, Saavedra SS. Molecular orientation distributions in protein films. V. Cytochrome $c$ adsorbed to a sulfonate-terminated self-assembled monolayer. Langmuir 2003;19:6443-6448.

64. Soellner MB, Dickson KA, Nilsson BL, Raines RT. Site-specific protein immobilization by Staudinger ligation. J. Am. Chem. Soc 2003;125:11790-11791. [PubMed: 14505380]

65. Liu X, C.-H J, Zheng F, Jürgensen A, Denslinger JD, Dickson KA, Raines RT, Abbott NL, Himpsel FJ. Characterization of protein immobilization at silver surfaces by near edge X-ray absorption fine structure spectroscopy. Langmuir 2006;22:7719-7725. [PubMed: 16922555]

66. de Graaf AJ, Kooijman M, Hennink WE, Mastrobattista E. Nonnatural amino acids for site-specific protein conjugation. Bioconjugate Chem 2009;20:1281-1295.

67. Binder JB, Raines RT. Olefin metathesis for chemical biology. Curr. Opin. Chem. Biol 2008;12:767773. [PubMed: 18935975]

68. Lin YA, Chalker JM, Davis BG. Olefin metathesis for site-selective protein modification. ChemBioChem 2009;10:959-969. [PubMed: 19343741]

69. Antos JM, Francis MB. Transition metal catalyzed methods for site-selective protein modification. Curr. Opin. Chem. Biol 2006;10:253-262. [PubMed: 16698310]

70. Bednar RA. Reactivity and $\mathrm{pH}$ dependence of thiol conjugation to $N$-ethylmaleimide: Detection of a conformational change in chalcone isomerase. Biochemistry 1990;29:3684-3690. [PubMed: 2340265]

71. Chalker JM, Bernardes GJ, Lin YA, Davis BG. Chemical modification of proteins at cysteine: Opportunities in chemistry and biology. Chem. Asian J 2009;4:630-640. [PubMed: 19235822]

72. McCaldon P, Argos P. Oligopeptide biases in protein sequences and their use in predicting protein coding regions in nucleotide sequences. Proteins 1988;4:99-122. [PubMed: 3227018]

73. Gurd FRN. Carboxymethylation. Methods Enzymol 1972;25:424-438.

74. Nielsen ML, Vermeulen M, Bonaldi T, Cox J, Moroder L, Mann M. Iodoacetamide-induced artifact mimics ubiquitination in mass spectrometry. Nat. Meth 2008;5:459-460.

75. Lavis LD, Chao T-Y, Raines RT. Fluorogenic label for biomolecular imaging. ACS Chem. Biol 2006;1:252-260. [PubMed: 17163679]

76. Kalia J, Raines RT. Catalysis of imido group hydrolysis in a maleimide conjugate. Bioorg. Med. Chem. Lett 2007;17:6286-6289. [PubMed: 17881230]

77. Armstrong N, Jasti J, Beich-Frandsen M, Gouaux E. Measurement of conformational changes accompanying desensitization in an ionotropic glutamate receptor. Cell 2006;127:85-97. [PubMed: 17018279]

78. Li M, Yamato K, Ferguson JS, Singarapu KK, Szyperski T, Gong B. Sequence-specific, dynamic covalent crosslinking in aqueous media. J. Am. Chem. Soc 2008;130:491-500. [PubMed: 18092773]

79. Yeo DS, Panicker RC, Tan LP, Yao SQ. Strategies for immobilization of biomolecules in a microarray. Comb. Chem. High. Throughput Screen 2004;7:213-221. [PubMed: 15134527]

80. Erianson DA, Wells JA, Braisted AC. Tethering: Fragment-based drug discovery. Annu. Rev. Biophys. Biomol. Struct 2004;33:199-223. [PubMed: 15139811]

81. Radzicka A, Wolfenden R. Rates of uncatalyzed peptide bond hydrolysis in neutral solution and the transition state affinities of proteases. J. Am. Chem. Soc 1996;118:6105-6109. 
82. Lahiri J, Isaacs L, Tien J, Whitesides GM. A strategy for the generation of surfaces presenting ligands for studies of binding based on an active ester as a common reactive intermediate: A surface plasmon resonance study. Anal. Chem 1999;71:777-790. [PubMed: 10051846]

83. Nilsson BL, Soellner MB, Raines RT. Chemical synthesis of proteins. Annu. Rev. Biophys. Biomolec. Struct 2005;34:91-118.

84. Dawson PE, Muir TW, Clarklewis I, Kent SBH. Synthesis of proteins by native chemical ligation. Science 1994;266:776-779. [PubMed: 7973629]

85. Dawson PE, Kent SBH. Synthesis of native proteins by chemical ligation. Annu. Rev. Biochem 2000;69:923-960. [PubMed: 10966479]

86. Kent S. Total chemical synthesis of enzymes. J. Pept. Sci 2003;9:574-593. [PubMed: 14552420]

87. Yeo DSY, Srinivasan R, Chen GYJ, Yao SQ. Expanded utility of the native chemical ligation reaction. Chem. Eur. J 2004;10:4664-4672.

88. Dirksen A, Dawson PE. Expanding the scope of chemoselective peptide ligations in chemical biology. Curr. Opin. Chem. Biol 2008;12:760-766. [PubMed: 19058994]

89. Evans TC Jr, Xu M-Q. Mechanistic and kinetic considerations of protein splicing. Chem. Rev 2002;102:4869-4883. [PubMed: 12475209]

90. Muir TW. Semisynthesis of proteins by expressed protein ligation. Annu. Rev. Biochem 2003;72:249-289. [PubMed: 12626339]

91. Flavell RR, Muir TW. Expressed protein ligation (EPL) in the study of signal transduction, ion conduction, and chromatin biology. Acc. Chem. Res 2009;42:107-116. [PubMed: 18939858]

92. Camarero JA, Kwon Y, Coleman MA. Chemoselective attachment of biologically active proteins to surfaces by expressed protein ligation and its application for "protein chip" fabrication. J. Am. Chem. Soc 2004;126:14730-14731. [PubMed: 15535692]

93. Wood RJ, Pascoe DD, Brown ZK, Medlicott EM, Kriek M, Neylon C, Roach PL. Optimized conjugation of a fluorescent label to proteins via intein-mediated activation and ligation. Bioconjugate Chem 2004;15:366-372.

94. Lue RY, Chen GY, Hu Y, Zhu Q, Yao SQ. Versatile protein biotinylation strategies for potential high-throughput proteomics. J. Am. Chem. Soc 2004;126:1055-1062. [PubMed: 14746473]

95. Raines RT. Nature's transitory covalent bond. Nat. Struct. Biol 1997;4:424-427. [PubMed: 9187645]

96. Friedman M. Lysinoalanine in food and in antimicrobial proteins. Adv. Exp. Med. Biol 1999;459:145159. [PubMed: 10335374]

97. Terrettax W, Ulrich WP, Vogel H, Hong Q, Dover LG, Lakey JH. Stable self-assembly of a protein engineering scaffold on gold surfaces. Protein Sci 2002;11:1917-1925. [PubMed: 12142446]

98. Yan LZ, Dawson PE. Synthesis of peptides and proteins without cysteine residues by native chemical ligation combined with desulfurization. J. Am. Chem. Soc 2001;123:526-533. [PubMed: 11456564]

99. Kalia J, Raines RT. Reactivity of intein thioesters: Appending a functional group to a protein. ChemBioChem 2006;7:1375-1383. [PubMed: 16897799]

100. Kalia J, Abbott NL, Raines RT. General method for site-specific protein immobilization by Staudinger ligation. Bioconjugate Chem 2007;18:1064-1069.

101. Köhn M, Breinbauer R. The Staudinger ligation-A gift to chemical biology. Angew. Chem. Int. Ed 2004;43:3106-3116.

102. Staudinger H, Meyer J. New organic compounds of phosphorus. III. Phosphinemethylene derivatives and phosphinimines. Helv. Chim. Acta 1919;2:635-646.

103. Gololobov YG, Kasukhin LF. Recent advances in the Staudinger reaction. Tetrahedron 1992;48:1353-1406.

104. Lin FL, Hoyt HM, van Halbeek H, Bergman RG, Bertozzi CR. Mechanistic investigation of the Staudinger ligation. J. Am. Chem. Soc 2005;127:2686-2695. [PubMed: 15725026]

105. Soellner MB, Nilsson BL, Raines RT. Reaction mechanism and kinetics of the traceless Staudinger ligation. J. Am. Chem. Soc 2006;128:8820-8828. [PubMed: 16819875]

106. Saxon E, Bertozzi CR. Cell surface engineering by a modified Staudinger reaction. Science 2000;287:2007-2010. [PubMed: 10720325] 
107. Luchansky SJ, Hang HC, Saxon E, Grunwell JR, Yu C, Dube DH, Bertozzi CR. Constructing azidelabeled cell surfaces using polysaccharide biosynthetic pathways. Methods Enzymol 2003;362:249-272. [PubMed: 12968369]

108. Nilsson BL, Kiessling LL, Raines RT. Staudinger ligation: A peptide from a thioester and azide. Org. Lett 2000;2:1939-1941. [PubMed: 10891196]

109. Nilsson BL, Kiessling LL, Raines RT. High-yielding Staudinger ligation of a phosphinothioester and azide to form a peptide. Org. Lett 2001;3:9-12. [PubMed: 11429880]

110. Soellner MB, Nilsson BL, Raines RT. Staudinger ligation of $\alpha$-azido acids retains stereochemistry. J. Org. Chem 2002;67:4993-4996. [PubMed: 12098322]

111. Nilsson BL, Hondal RJ, Soellner MB, Raines RT. Protein assembly by orthogonal chemical ligation methods. J. Am. Chem. Soc 2003;125:5268-5269. [PubMed: 12720426]

112. Tam A, Raines RT. Protein engineering with the traceless Staudinger ligation. Methods Enzymol 2009;462:25-44. [PubMed: 19632468]

113. Saxon E, Luchansky SJ, Hang HC, Yu C, Lee SC, Bertozzi CR. Investigating cellular metabolism of synthetic azidosugars with the Staudinger ligation. J. Am. Chem. Soc 2002;124:14893-14902. [PubMed: 12475330]

114. He Y, Hinklin RJ, Chang J, Kiessling LL. Stereoselective $N$-glycosylation by Staudinger ligation. Org. Lett 2004;6:4479-4482. [PubMed: 15548055]

115. Kiick KL, Saxon E, Tirrell DA, Bertozzi CR. Incorporation of azides into recombinant proteins for chemoselective modification by the Staudinger ligation. Proc. Natl. Acad. Sci. U.S.A 2002;99:1924. [PubMed: 11752401]

116. van Dongen SFM, Teeuwen RLM, Nallani M, van Berkel SS, Cornelissen JJLM, Nolte RJM, van Hest JCM. Single-step azide introduction in proteins via an aqueous diazo transfer. Bioconjugate Chem 2008;20:20-23.

117. Köhn M, Wacker R, Peters C, Schröder H, Soulère L, Breinbauer R, Niemeyer CM, Waldmann H. Staudinger ligation: A new immobilization strategy for the preparation of small-molecule arrays. Angew. Chem. Int. Ed 2003;42:5830-5834.

118. Gauchet C, Labadie GR, Poulter CD. Regio- and chemoselective covalent immobilization of proteins through unnatural amino acids. J. Am. Chem. Soc 2006;128:9274-9275. [PubMed: 16848430]

119. Wang CC, Seo TS, Li Z, Ruparel H, Ju J. Site-specific fluorescent labeling of DNA using Staudinger ligation. Bioconjugate Chem 2003;14:697-701.

120. Zhang J, Wang H, Xian M. An unexpected bis-ligation of $S$-nitrosothiols. J. Am. Chem. Soc 2009;131:3854-3855. [PubMed: 19256495]

121. Myers EL, Raines RT. A phosphine-mediated conversion of azides into diazo compounds. Angew. Chem. Int. Ed 2009;48:2359-2363.

122. Tietze LF, Arlt M, Beller M, Glüsenkamp KH, Jähde E, Rajewsky MF. Squaric acid diethyl ester: A new coupling reagent for the formation of drug biopolymer conjugates. Synthesis of squaric acid ester amides and diamides. Chem. Ber 1991;124:1215-1221.

123. Kamath VP, Diedrich P, Hindsgaul O. Use of diethyl squarate for the coupling of oligosaccharide amines to carrier proteins and characterization of the resulting neoglycoproteins by MALDI-TOF mass spectrometry. Glycoconjugate J 1996;13:315-319.

124. Carlson CB, Mowery P, Owen RM, Dykhuizen EC, Kiessling LL. Selective tumor cell targeting using low-affinity, multivalent interactions. ACS Chem. Biol 2007;2:119-127. [PubMed: 17291050]

125. Cordes EH, Jencks WP. Nucleophilic catalysis of semicarbazone formation by anilines. J. Am. Chem. Soc 1962;84:826-831.

126. Dirksen A, Hackeng TM, Dawson PE. Nucleophilic catalysis of oxime ligation. Angew. Chem. Int. Ed 2006;45:7581-7584.

127. Dirksen A, Dirksen S, Hackeng TM, Dawson PE. Nucleophilic catalysis of hydrazone formation and transimination: Implications for dynamic covalent chemistry. J. Am. Chem. Soc 2006;128:15602-15603. [PubMed: 17147365]

128. Dirksen A, Dawson PE. Rapid oxime and hydrazone ligations with aromatic aldehydes for biomolecular labeling. Bioconjugate Chem 2008;19:2543-2548. 
129. Wilchek M, Bayer EA. Labeling glycoconjuagtes with hydrazide reagents. Methods Enzymol 1987;138:429-442. [PubMed: 3110546]

130. Mahal LK, Yarema KJ, Bertozzi CR. Engineering chemical reactivity on cell surfaces through oligosaccharide biosynthesis. Science 1997;276:1125-1128. [PubMed: 9173543]

131. Keppler OT, Horstkorte R, Pawlita M, Schmidt C, Reutter W. Biochemical engineering of the $N$ acyl side chain of sialic acid: Biological implications. Glycobiology 2001;11:11R-18R. [PubMed: 11181557]

132. Gama CI, Tully SE, Sotogaku N, Clark PM, Rawat M, Vaidehi N, Goddard WA 3rd, Nishi A, HsiehWilson LC. Sulfation patterns of glycosaminoglycans encode molecular recognition and activity. Nat. Chem. Biol 2006;2:467-473. [PubMed: 16878128]

133. Zatsepin TS, Stetsenko DA, Gait MJ, Oretskaya TS. Use of carbonyl group addition-elimination reactions for synthesis of nucleic acid conjugates. Bioconjugate Chem 2005;16:471-489.

134. Kremsky JN, Wooters JL, Dougherty JP, Meyers RE, Collins M, Brown EL. Immobilization of DNA via oligonucleotides containing an aldehyde or carboxylic acid group at the 5' terminus. Nucleic Acids Res 1987;15:2891-2909. [PubMed: 3562241]

135. Neuner P, Gallo P, Orsatti L, Fontana L, Monaci P. An efficient and versatile synthesis of bisPNApeptide conjugates based on chemoselective oxime formation. Bioconjugate Chem 2003;14:276281.

136. Melnyk O, Duburcq X, Olivier C, Urbes F, Auriault C, Gras-Masse H. Peptide arrays for highly sensitive and specific antibody-binding fluorescence assays. Bioconjugate Chem 2002;13:713-720.

137. Duburcq X, Olivier C, Malingue F, Desmet R, Bouzidi A, Zhou F, Auriault C, Gras-Masse H, Melnyk O. Peptide-pathogen microarrays for the simultaneous detection of pathogen infections. Bioconjugate Chem 2004;15:307-316.

138. Falsey JR, Renil M, Park S, Li S, Lam KS. Peptide and small molecule microarray for high throughput cell adhesion and functional assays. Bioconjugate Chem 2001;12:346-353.

139. Rose K. Facile synthesis of homogeneous artificial proteins. J. Am. Chem. Soc 1994;116:30-33.

140. Rose K, Zeng W, Ragamey P-O, Chernushevich IV, Standing KG, Gaertner HF. Natural peptides as building blocks for the synthesis of large protein like molecules with hydrazone and oxime linkages. Bioconjugate Chem 1996;7:552-556.

141. Canne LE, Ferre-D’Amare AR, Burley SK, Kent SBH. Total chemical synthesis of a unique transcription factor-related protein: cMyc-Max. J. Am. Chem. Soc 1995;117:2998-3007.

142. Grandjean C, Rommens C, Gras-Masse H, Melnyk O. One-pot synthesis of antigen-bearing lysinebased cluster mannosides using two orthogonal chemoselective ligation reactions. Angew. Chem. Int. Ed 2000;39:1068-1072.

143. Grandjean C, Santraine V, Fruchart J-S, Melnyk O, Gras-Masse H. Combined thioether/hydrazone chemoselective ligation reactions for the synthesis of glycocluster-antigen peptide conjugates. Bioconjugate Chem 2002;13:887-892.

144. Snell EE. The vitamin $\mathrm{B}_{6}$ group. V. The reversible interconversion of pyridoxal and pyridoxamine by transamination reactions. J. Am. Chem. Soc 1945;67:194-197.

145. Scheck RA, Dedeo MT, Iavarone AT, Francis MB. Optimization of a biomimetic transamination reaction. J. Am. Chem. Soc 2008;130:11762-11770. [PubMed: 18683929]

146. Kalia J, Raines RT. Hydrolytic stability of hydrazones and oximes. Angew. Chem. Int. Ed 2008;47:7523-7526.

147. Rostovtsev VV, Green LG, Fokin VV, Sharpless KB. Angew. Chem. Int. Ed 2002;41:2596-2599.

148. Tornøe CW, Christensen C, Meldal M. Peptidotriazoles on solid phase: [1,2,3]-Triazoles by regiospecific copper(I)-catalyzed 1,3-dipolar cycloadditions of terminal alkynes to azides. J. Org. Chem 2002;67:3057-3064. [PubMed: 11975567]

149. Moses JE, Moorhouse AD. The growing applications of click chemistry. Chem. Soc. Rev 2007;36:1249-1262. [PubMed: 17619685]

150. Hein CD, Liu XM, Wang D. Click chemistry, a powerful tool for pharmaceutical sciences. Pharm. Res 2008;25:2216-2230. [PubMed: 18509602]

151. Meldal M, Tornøe CW. Cu-catalyzed azide-alkyne cycloaddition. Chem. Rev 2008;108:2952-3015. [PubMed: 18698735] 
152. Zhou Z, Fahrni CJ. A fluorogenic probe for the copper(I)-catalyzed azide-alkyne ligation reaction: Modulation of the fluorescence emission via ${ }^{3}\left(\mathrm{n}, \pi^{*}\right)-{ }^{1}\left(\pi, \pi^{*}\right)$ inversion. J. Am. Chem. Soc 2004;126:8862-8863. [PubMed: 15264794]

153. Macpherson LJ, Dubin AE, Evans MJ, Marr F, Schultz PG, Cravatt BF, Patapoutian A. Noxious compounds activate TRPA1 ion channels through covalent modification of cysteines. Nature 2007;445:541-545. [PubMed: 17237762]

154. Peschke B, Zundel M, Bak S, Clausen TR, Blume N, Pedersen A, Zaragoza F, Madsen K. CTerminally PEGylated hGH-derivatives. Bioorg. Med. Chem 2007;15:4382-4395. [PubMed: 17482822]

155. Sun XL, Stabler CL, Cazalis CS, Chaikof EL. Carbohydrate and protein immobilization onto solid surfaces by sequential Diels-Alder and azide-alkyne cycloadditions. Bioconjugate Chem 2006;17:52-57.

156. Speers AE, Adam GC, Cravatt BF. Activity-based protein profiling in vivo using a copper(I)catalyzed azide-alkyne [3 + 2] cycloaddition. J. Am. Chem. Soc 2003;125:4686-4687. [PubMed: 12696868]

157. Gramlich PM, Wirges CT, Manetto A, Carell T. Postsynthetic DNA modification through the copper-catalyzed azide-alkyne cycloaddition reaction. Angew. Chem. Int. Ed 2008;47:8350-8358.

158. Wang Q, Chan TR, Hilgraf R, Fokin VV, Sharpless KB, Finn MG. Bioconjugation by copper(I)catalyzed azide-alkyne [3 + 2] cycloaddition. J. Am. Chem. Soc 2003;125:3192-3193. [PubMed: 12630856]

159. Mangold SL, Carpenter RT, Kiessling LL. Synthesis of fluorogenic polymers for visualizing cellular internalization. Org. Lett 2008;10:2997-3000. [PubMed: 18563907]

160. Boren BC, Narayan S, Rasmussen LK, Zhang L, Zhao H, Lin Z, Jia G, Fokin VV. Rutheniumcatalyzed azide-alkyne cycloaddition: Scope and mechanism. J. Am. Chem. Soc 2008;130:89238930. [PubMed: 18570425]

161. Tam A, Arnold U, Soellner MB, Raines RT. Protein prosthesis: 1,5-Disubstituted[1,2,3]triazoles as cis-peptide bond surrogates. J. Am. Chem. Soc 2007;129:12670-12671. [PubMed: 17914828]

162. Blomquist AT, Liu LH. Many-membered carbon rings. VII. Cycloöctyne. J. Am. Chem. Soc 1953;75:2153-2154.

163. Wittig G, Krebs A. On the existence of low-membered cycloalkynes. I. Chem. Ber 1961;94:32603275 .

164. Banert K, Köhler F. Synthesis of 1,4-diazidobuta-1,3-dienes by electrocyclic ring opening: Precursors for bi- $\mathrm{H}$-azirin-2-yls and their valence isomerization to diazabenzene. Angew. Chem. Int. Ed 2001;40:174-177.

165. Agard NJ, Prescher JA, Bertozzi CR. A strain-promoted [3+2] azide-alkyne cycloaddition for covalent modification of biomolecules in living systems. J. Am. Chem. Soc 2004;126:1504615047. [PubMed: 15547999]

166. Lutz J-F. Copper-free azide-alkyne cycloadditions: New insights and perspectives. Angew. Chem. Int. Ed 2008;47:2182-2184.

167. Ning X, Guo J, Wolfert MA, Boons G-J. Visualizing metabolically labeled glycoconjugates of living cells by copper-free and fast Huisgen cycloadditions. Angew. Chem. Int. Ed 2008;47:2253-2255.

168. Houseman BT, Huh JH, Kron SJ, Mrksich M. Peptide chips for the quantitative evalution of protein kinase activity. Nat. Biotechnol 2002;20:270-274. [PubMed: 11875428]

169. Houseman BT, Mrksich M. Carbohydrate arrays for the evaluation of protein binding and enzymatic modification. Chem. Biol 2002;9:443-454. [PubMed: 11983333]

170. Blackman ML, Royzen M, Fox JM. Tetrazine ligation: Fast bioconjugation based on inverseelectron-demand Diels-Alder reactivity. J. Am. Chem. Soc 2008;130:13518-13519. [PubMed: 18798613]

171. Bräse S, Gil C, Knepper K, Zimmermann V. Organic azides: An exploding diversity of a unique class of compounds. Angew. Chem. Int. Ed 2005;44:5188-5240.

172. Agard NJ, Baskin JM, Prescher JA, Lo A, Bertozzi CR. A comparative study of bioorthogonal reactions with azides. ACS Chem. Biol 2006;1:644-648. [PubMed: 17175580]

173. Los GV, Encell LP, McDougall MG, Hartzell DD, Karassina N, Zimprich C, Wood MG, Learish R, Ohana RF, Urh M, Simpson D, Mendez J, Zimmerman K, Otto P, Vidugiris G, Zhu J, Darzins 
A, Klaubert DH, Bulleit RF, Wood KV. HaloTag: A novel protein labeling technology for cell imaging and protein analysis. ACS Chem. Biol 2008;3:373-382. [PubMed: 18533659] 


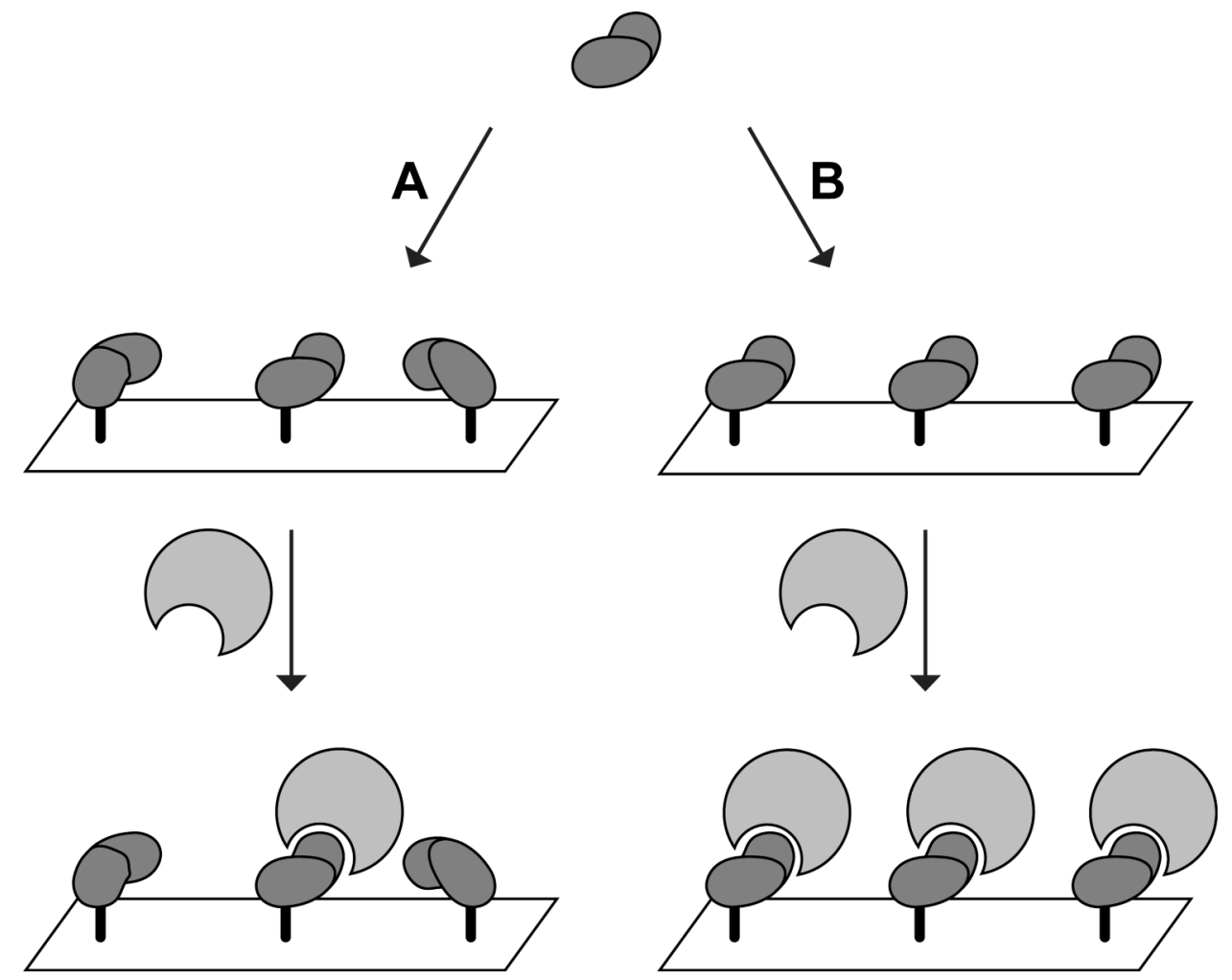

Fig. (1).

Random and site-specific bioconjugation. Ligands are immobilized to a surface at (A) multiple sites, or (B) a single site; and are then probed with a cognate receptor. 


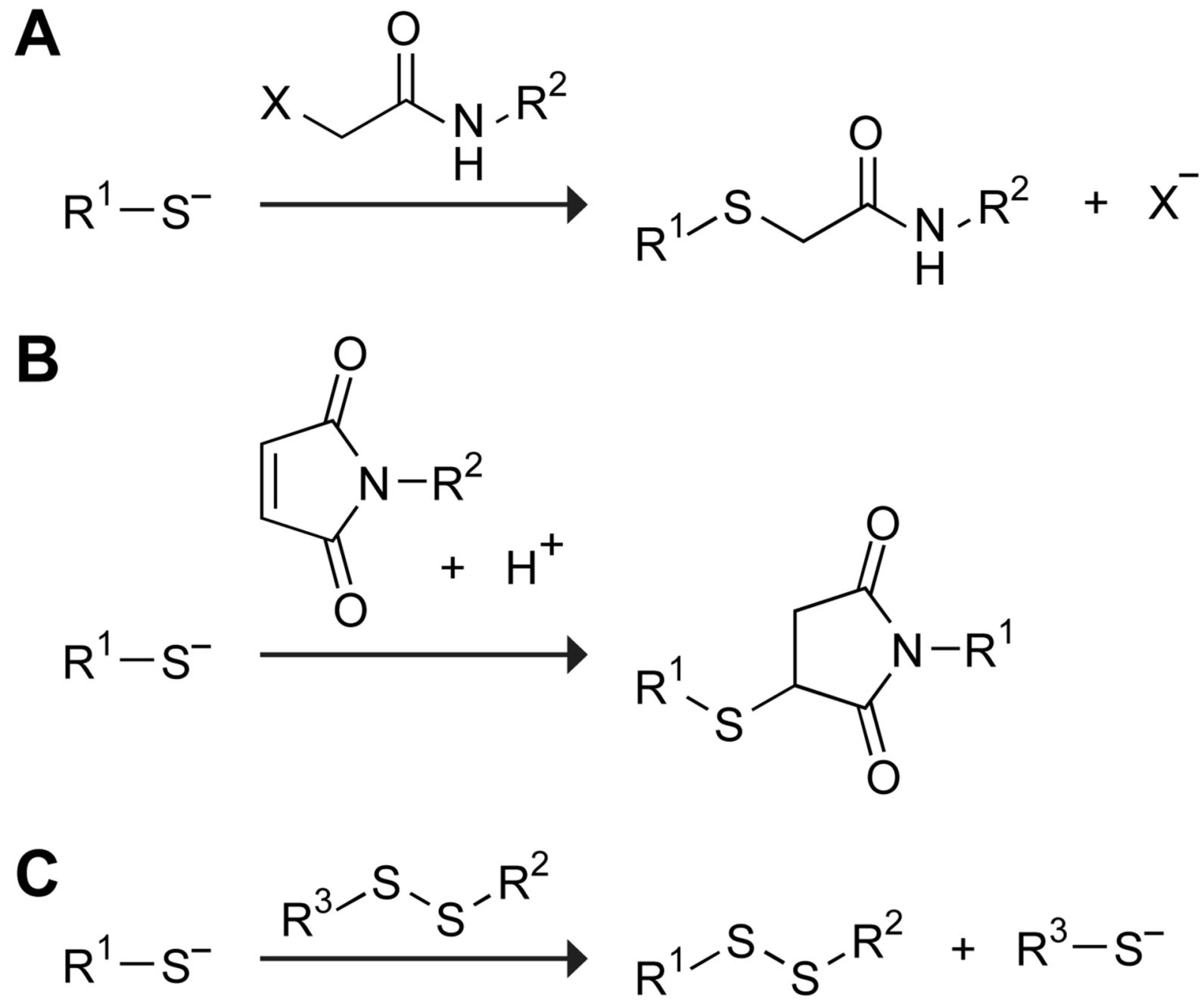

Fig. (2).

Bioconjugation via thioethers or disulfides. Reaction of a thiolate with (A) a haloacetamide, (B) a maleimide, and (C) a disulfide. 
<smiles>[R]OC([R])CC([R])=O</smiles><smiles>[R]SC([R])CSC([R])=O</smiles>

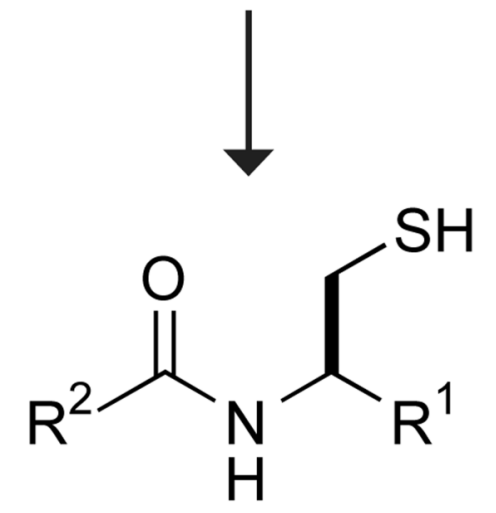

Fig. (3).

Amide bond formation via native chemical ligation. An $\mathrm{N}$-terminal cysteine residue reacts with a thioester, which after an $S \rightarrow N$ acyl shift leads to an amide bond. 


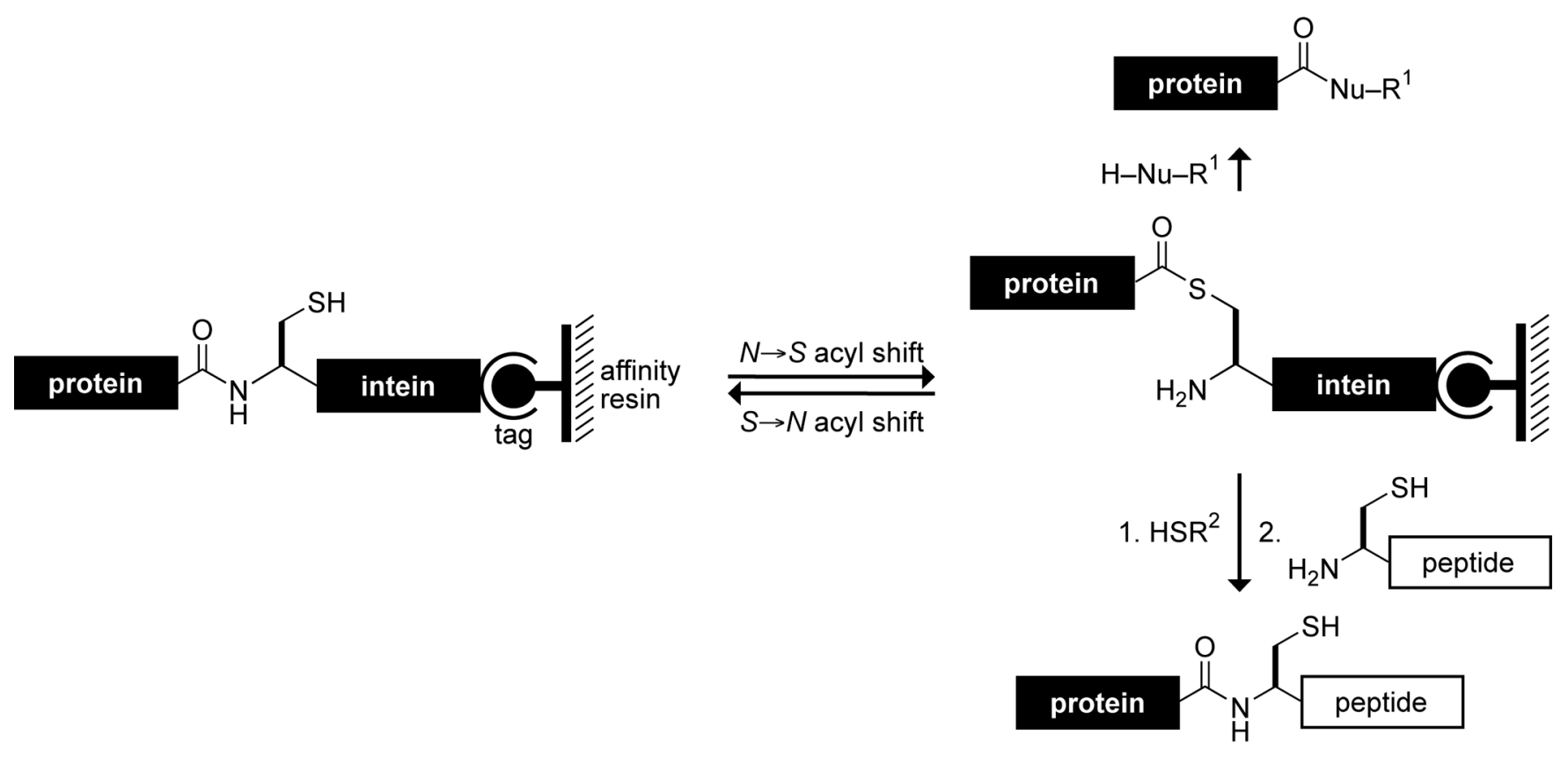

Fig. (4).

Amide bond formation via expressed protein ligation. An intein installs a thioester at the $\mathrm{C}$ terminus of the target protein, which undergoes native chemical ligation with a peptide containing an $\mathrm{N}$-terminal cysteine residue. Protein-intein thioesters can be treated with other nucleophiles $(\mathrm{H}-\mathrm{Nu})$ to install functional groups or surfaces at the $\mathrm{C}$ terminus. 
A<smiles>[R]NNC(=O)c1cc[R]([CH+]C)cc1P(=O)(O)c1ccccc1[PH2+]</smiles>

B

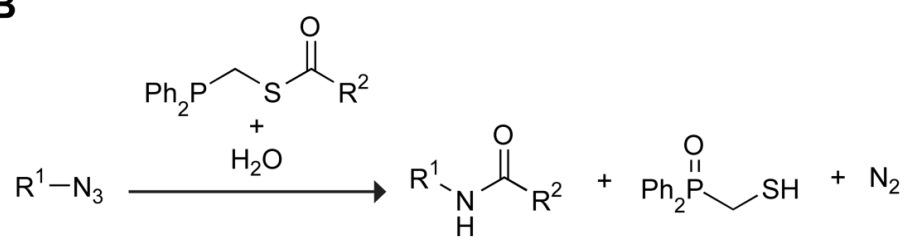

C

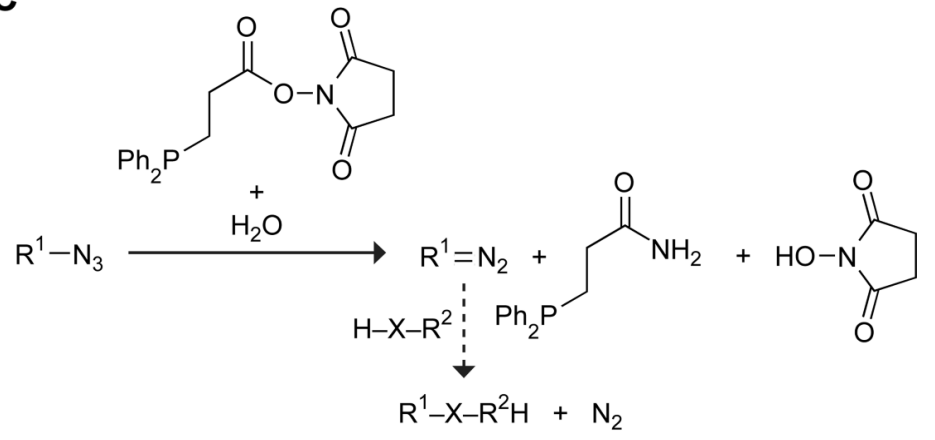

D

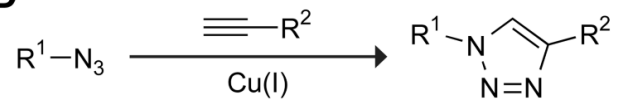

$\mathbf{E}$

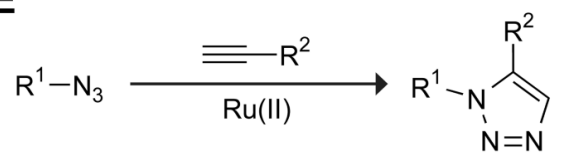

$\mathbf{F}$

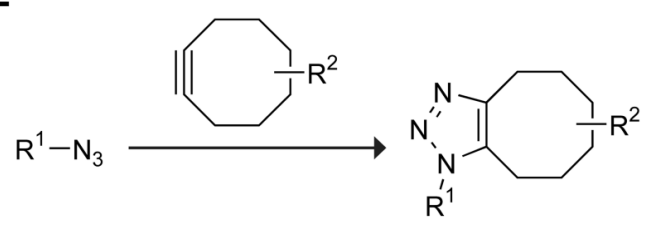

Fig. (5).

Bioconjugation via azido groups. (A) Non-traceless Staudinger ligation. (B) Traceless Staudinger ligation. (C) Reductive cleavage to a diazo compound, which could be followed by carbene-mediated crosslinking. (D) $\mathrm{Cu}(\mathrm{I})$-catalyzed Huisgen 1,3-dipolar azide-alkyne cycloaddition. (E) $\mathrm{Cu}(\mathrm{I})$-catalyzed Huisgen 1,3-dipolar azide-alkyne cycloaddition. (F) Straininduced Huisgen 1,3-dipolar azide-alkyne cycloaddition. 


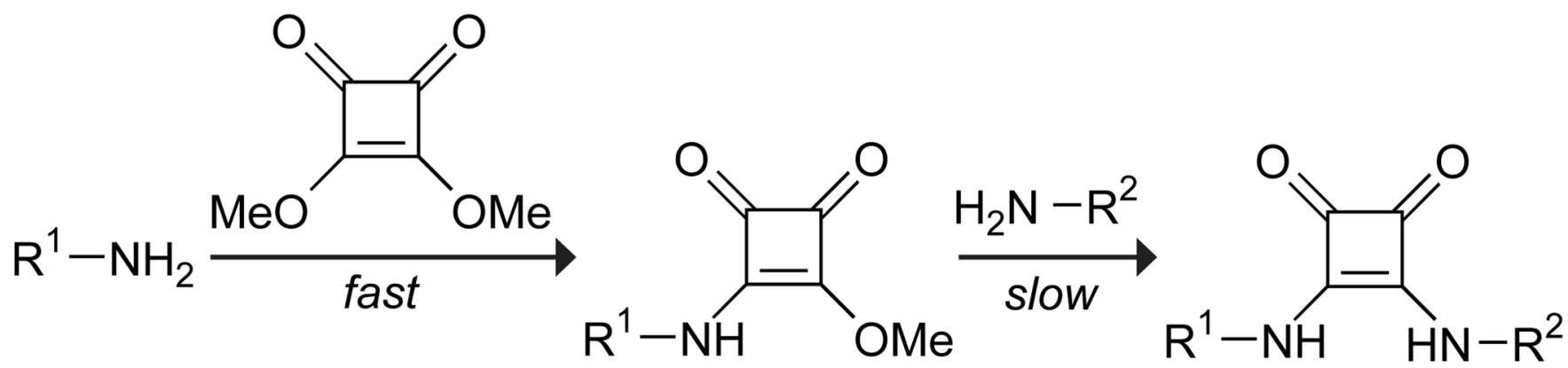

Fig. (6).

Bioconjugation via a squarate. 


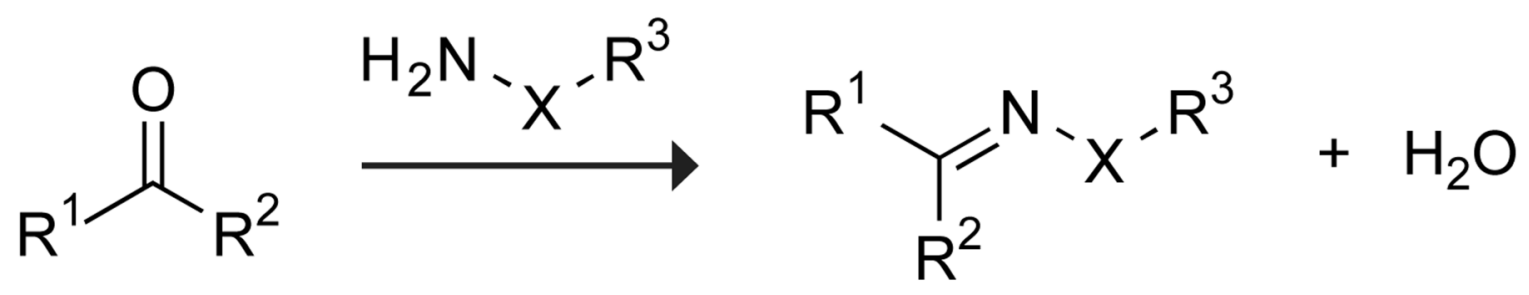

Fig. (7).

Bioconjugation via carbon-nitrogen double bonds. $\mathrm{X}=\mathrm{O}$ in oximes, $\mathrm{NH}$ in alkylhydrazones, and $\mathrm{NHC}(\mathrm{O})$ in acylhydrazones. 